\title{
Modelbuilder and Unit Hydrograph for Flood Prediction and Watershed Flow Direction Determination at The West Branch of The Little River, Stowe, Lamoille County, Vermont, USA
}

\author{
F. E. S. Silalahia ${ }^{a, b^{*}}$ (D) , F. Hidayat ${ }^{\mathrm{b}}$ \\ ${ }^{a}$ Western Michigan University, Geological and Environmental Sciences, USA \\ ${ }^{b}$ Geospatial Information Agency, Indonesia
}

\section{Article Info:}

Received: 11 July 2019

in revised form: 11 September 2019

Accepted: 11 November 2019

Available Online: 30 December 2019

\section{Keywords:}

Little River, Flood, Unit Hydrograph, Geographic Information Systems

(GIS), ArcGIS Pro

*Corresponding Author: Florence Silalahi

Western Michigan University, Geological and Environmental Sciences, USA

Email: florenceelfriede@gmail.com

\begin{abstract}
The West Branch of the Little River in Stowe, Lamoille County, Vermont has been widely studied, and this area is regularly subject to flooding. The West Branch joins the Little River, which flows into the Winooski and drains into Lake Champlain. This area has undergone extensive development as an economic response to the ski resort industry over the past 50 years, and the recreational pathway is on the banks of the river. The Little River is adjusting to the loss of historic floodplain area, channel modifications (straightening and gravel mining), and runoff changes. In this project, a DEM with 10 and 30 meters resolution will be used to determine the watershed area for the outlet point at the south of Stowe for hydrological analysis. This project intends to describe the watershed flow direction with a unit hydrograph that shows when water discharge at the outlet is at its height during a rainfall event and produce the floods prediction map by predicting the nature of flood events to help in planning and responding to flood events effectively using ArcGIS Pro 2.0. The results show the time it takes water to flow to the outlet ranges from 0 seconds (rain that falls on the outlet itself) to over 8 hours and 46 minutes. The amount of water has accumulated, indicating that water will flow at its fastest when funneling toward the outlet point downstream of the town with no exception, indicating that water will flow at its fastest when funneling toward the outlet point downstream of the town.
\end{abstract}

Copyright (C) 2019 GJGP-UNDIP This open access article is distributed under Creative Commons Attribution (CC-BY-NC-SA) 4.0 International license.

How to cite (APA 6th Style):

Silalahi, F., \& Hidayat, F. (2020). Modelbuilder and Unit Hydrograph for Flood Prediction and Watershed Flow Direction Determination at The West Branch of The Little River, Stowe, Lamoille County, Vermont, USA. Geoplanning: Journal of Geomatics and Planning, 6(2), 89-98. doi: 10.14710/geoplanning.6.2.89-98

\section{INTRODUCTION}

Hydrological processes are complex (Khan, Yufeng, \& Ahmad, 2009). A proportion of the precipitation falls on the stream and river network directly and contributes to runoff. The rest of the precipitation reaches the ground, which infiltrates through the soils, directly contributing to surface runoff (Guéro, 2006). Runoff occurring on uplands flows downstream in various patterns affected by spatial and temporal distribution of rainfall, rate of snowmelt, hydraulics of streams, watershed and channel storage, geology, and soil characteristics, watershed surface and cover conditions (The U.S. Department of Agriculture, 2007). Understanding the effect of sediment and changing water input to streamflow is crucial, so it needs to know hydraulic resistance by understanding step-pool formations (Sulebakk, 2017; Maxwell \& Papanicolaou, 2001).

The West Branch of the Little River in Stowe, Lamoille County, Vermont has been widely studied because it is regularly subject to flooding. High flows that would normally access the floodplain are causing extensive bank erosion, channel widening, loss of aquatic habitat, and general channel instability (The Lamoille County Planning Commission, 2006). A previous study about peak discharges estimation and unit hydrographs was developed for streams in Charlotte and Mecklenburg County in 2003. Estimating unit 
hydrographs is an important component used in watershed modeling and (or) design of stormwatermanagement structures. The unit hydrograph includes three statistical relations, i.e., storm peak discharge, unit-hydrograph peak discharge, and unit-hydrograph lag time. The statistical relation to estimating the storm peak discharge is based on analyses of observed peak discharges regressed against rainfall and basin characteristics (Weaver, 2003).

Flood prediction involves the rainfall-runoff transformation processes based on empirical or combined conceptual physically-based descriptions of the processes involved, i.e., rainfall into a flood hydrograph and the translation of that hydrograph throughout a watershed or any other hydrologic system (Ramírez, 2000). The Unit Hydrograph is the surface runoff hydrograph resulting from one unit of rainfall excess, spatially and temporally distributed over a watershed uniformly for a specified duration, which was applied at the outlet of the sub-catchment(s) along the river (Guéro, 2006). Despite it categorization as a conservative method, the unit hydrograph remains a useful and practical approach to dealing with operational hydrological forecasting and rainfall-runoff modelling. Besides, this method can compute the predicted time to peak of runoff more accurately for time less than one hour (Kusumastuti \& Jokowinarno, 2012).

In this project, a digital elevation model (DEM) will be used to determine the watershed area for the outlet point at the south of Stowe and make it ready for hydrological analysis. It has 10 meters resolution and was derived from the United States Geological Survey (USGS). Besides, a pour point feature that depicts the outlet downstream of the Little River where a unit hydrograph will be created, a polygon boundary that depicts the boundaries of Stowe from Vermont Center for Geographic Information (VCGI), and a raster layer with 30 meters resolution that depicts the surface water bodies in the area derived from features in the NHDPlus Version 2 dataset are needed. This project intends to describe the watershed flow direction with a unit hydrograph that shows when water discharge at the outlet is at its height during a rainfall event and predicts flooding that will help plan and respond to flood events effectively.

\section{DATA AND METHODS}

As the study area (Figure 1), the West Branch joins the Little River, which flows into the Winooski and drains into Lake Champlain. At the Little River's confluence in the Village of Stowe, the elevation is about 695 feet above sea level. The Mountain Road and the Stowe Recreation Path parallel the West Branch for most of its length. Upstream of Ranch Brook, to where the main channel leaves Route 108 (north of Big Spring), the channel slope averages approximately $4.5 \%$ with a step-pool/cascade-pool morphology.

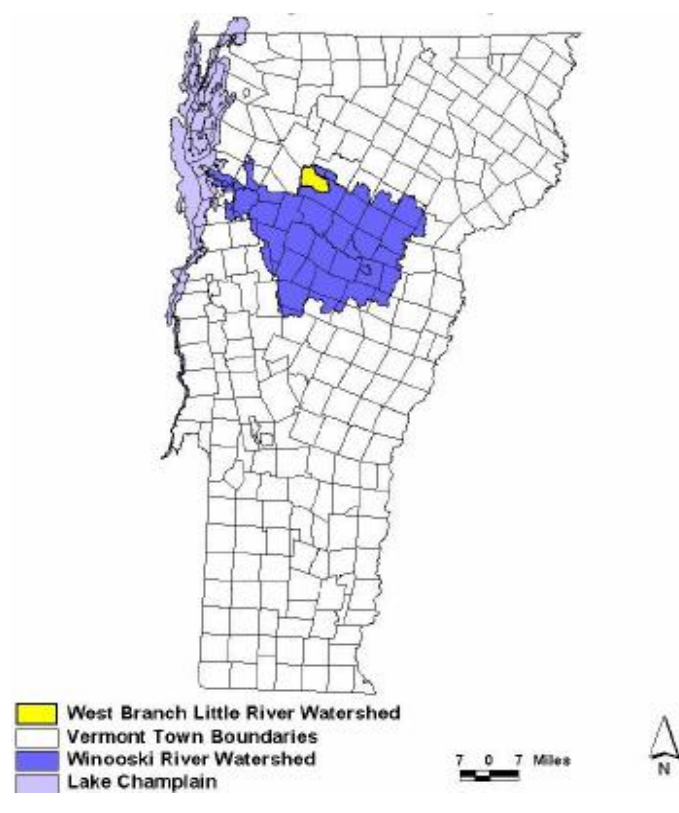

Figure 1. Map Location (The Lamoille County Planning Commission, 2006) 
Land use adjacent to the river is predominately agricultural, commercial, residential, and recreational. The valley post-glaciation contained a glacial lake that left well-drained, highly permeable soils up to high elevations in the modern valley. The glacial lake(s) also left behind extremely deep silt, sand, and gravel (The Lamoille County Planning Commission, 2006).

This area has undergone extensive development as an economic response to the ski resort industry over the past 50 years, and the recreation path is adjacent to most of the river, so the river is adjusting to the loss of historic floodplain, channel modifications (straightening and gravel mining), and changes in runoff. Between 1995 and 1998, Vermonters suffered nearly \$60,000,000 in flood damage. The majority of large twentieth-century floods have occurred during the summer (June through August) and are associated with intense cloudbursts, which stay in the mountains producing high rainfall amounts. The remainder is divided evenly between fall floods and winter/spring floods. The fall floods (September through November) are often associated with hurricanes. In contrast, the winter/spring floods (January through April) are associated with rain events, snow events, or snowmelt (The Lamoille County Planning Commission, 2006).

The study will begin with the precondition of the elevation model that requires DEM preparation to get accurate hydrological analysis for the area around Stowe. Precondition the elevation model steps, i.e., assessing the flow directions, identifying and fulfilling the sinks.

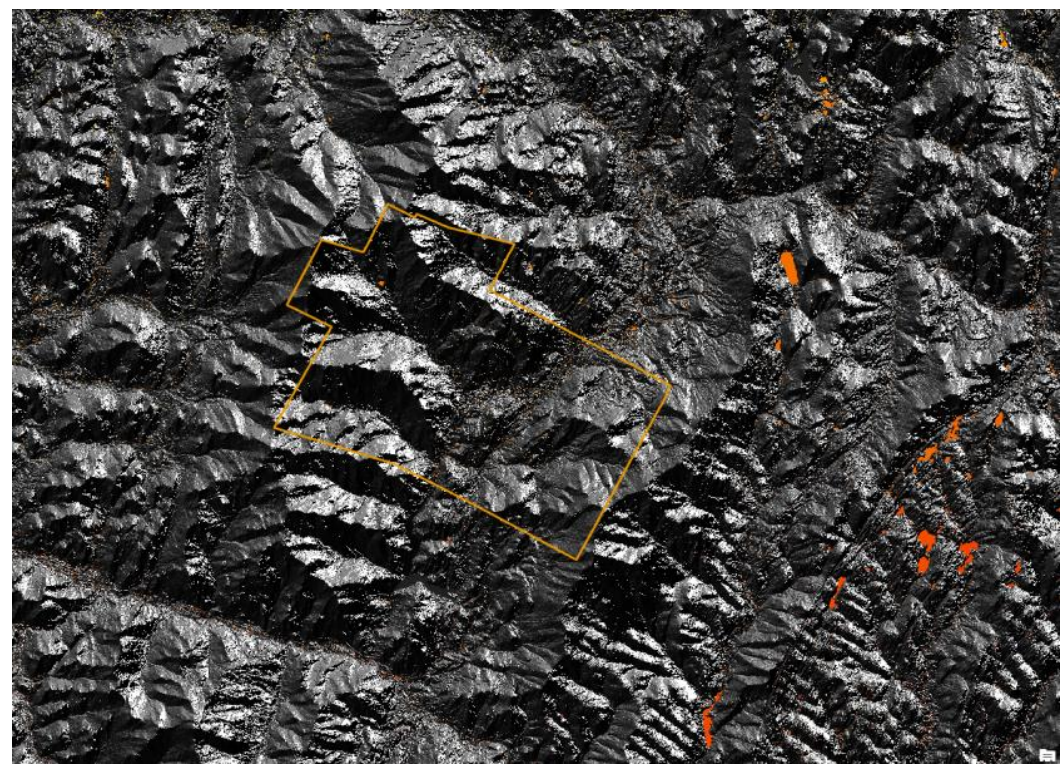

Figure 2. Result of Precondition (Sinks Locate as Orange Dot or Area)

The second process is to delineate the watershed. Watershed delineation requires a flow direction of the raster layer and an outlet point. The watershed delineating process includes assessing flow direction, assessing flow accumulation, and measuring the outlet point's distance. The pour point as an outlet may differ slightly due to the DEM's resolution or other inaccuracies. From the stream's actual location, the outlet must be precisely located on the stream as rendered in the DEM. So, in measuring the distance to the outlet point, the outlet point's location must be mapped to match the stream exactly and get an accurate watershed.

Delineating a watershed requires two components, i.e., a flow direction raster layer and an accurate outlet point. A watershed area is an area in which all flowing water will flow toward an outlet point using verified-DEM. The watershed represents all areas that flow to the specified outlet (Environmental Systems Research Institute, 2018). A watershed is mapped by determining the watershed area upstream of the outlet using the watershed tool in ArcGIS Pro. The watershed comprises almost the entirety of Stowe's town boundaries. This indicates rather than draining away, almost all rainfall that lands in Stowe will go rushing through the actual town. 
Along with data processing, it is necessary to build geoprocessing workflows. ModelBuilder will be used to develop flood hazard models for the study area (see Figure 3). ModelBuilder is a visual programming language and it can be exported to Python script (Kraemer \& Hale, 2014; Zandbergen, 2015). Geoprocessing models help spatial analysis process and documentation of data management automatically. ModelBuilder represents a process of geoprocessing tools as diagram chain sequences, using the output of one process as the input to another process. ModelBuilder needs geoprocessing tools, map layers, datasets, and other data types, and connect all of it into a process by running the model step-by-step, up to a selected step, or run the entire model (Armstrong, 2009; Allen, 2011; Kraemer \& Hale, 2014; Environmental Systems Research Institute, 2018). ModelBuilders obtained from GIS processing can be used to predict conditions related to simulation, evaluation, and discovery because it is able to explain the solutions to various problems in the spatial context. This model must answer at least six questions, which are related to identification of events, locations, trends, optimal paths, patterns, and models, for example damage to settlements due to lava flooding (Kumalawati et al., 2013), soil erosion in small forested catchment (Csáfordi et al., 2012), an earthquake-induce landslides risk assessment (Zhu, 2010), and flood hazard assessment based on basin morphometry (Omran et al., 2011). The ModelBuilder of this research was created using ArcGIS Pro 2.0.
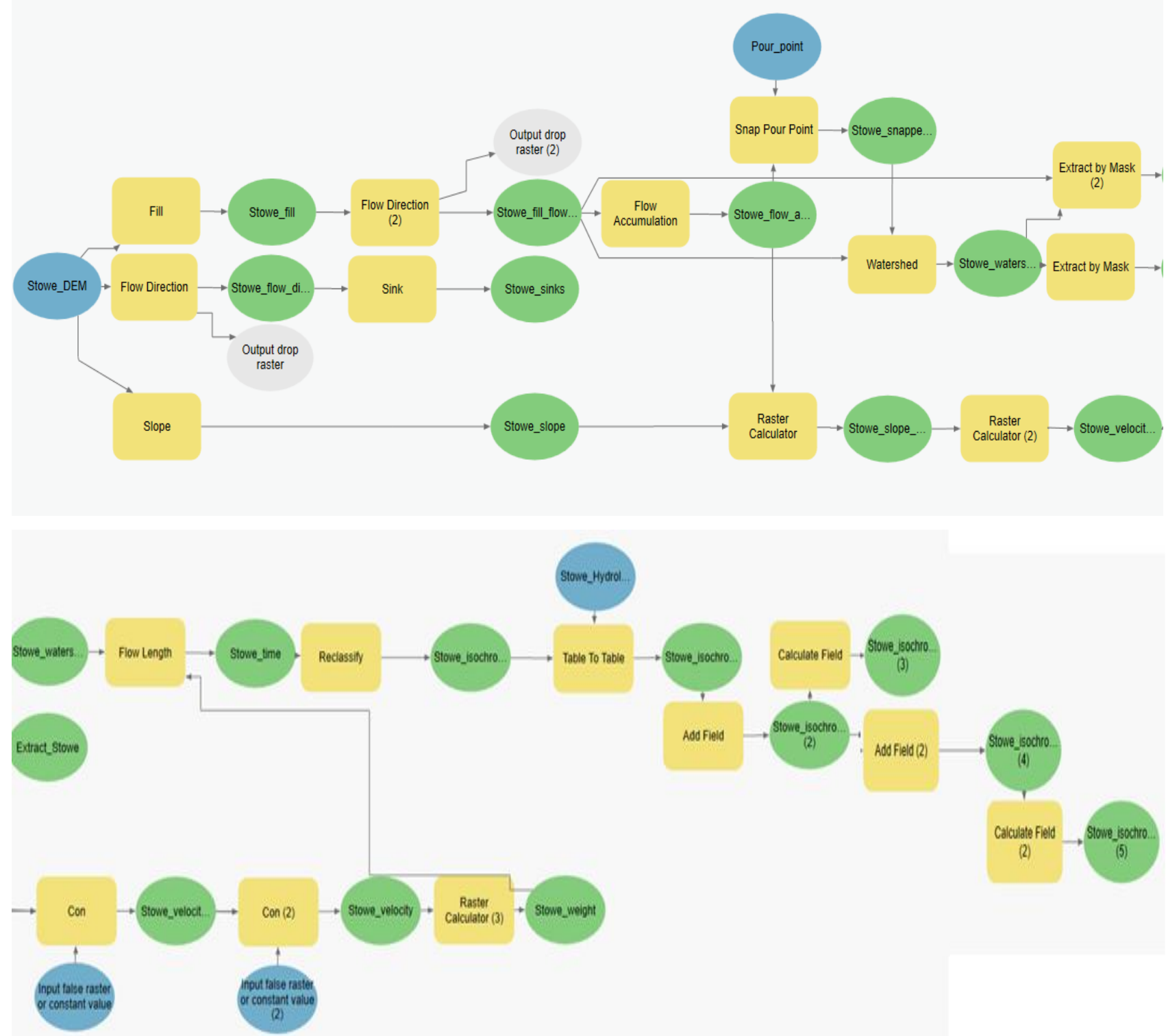

Figure 3. ModelBuilder of Flood Prediction and Watershed Flow Direction Determination at the West Branch of the Little River, Vermont, USA 
The third step is creating a velocity field and isochrones map. The process that needs to be completed from the data collection, processing process, and map creations is shown in Figure 2. Creating steps on a velocity field, i.e., creating the slope raster, calculating the slope-area term, calculating the velocity field, and determining the minimum and maximum velocities limit.

For the better prediction of flooding events, planes will need to know how long water flow will be and when the flow will reach the outlet during a hypothetical rainfall event. The speed of flowing water must be estimated with a velocity field. Construction of a velocity field requires several assumptions, i.e., 1) Velocity is spatially variant, which means it affected by slope and flow accumulation; 2) Velocity is uniform at a given location at a given time, which means it does not change over time; and 3) Velocity is discharging invariant at a given location, which means it does not depend on the location's rate of water (Environmental Systems Research Institute, 2018; The U.S. Department of Agriculture, 2007). These assumptions will provide a generally accurate velocity field as an approximation of observed phenomena.

The last step is creating a unit hydrograph. There are five classifications of hydrographs, i.e., natural hydrograph, hydrograph unit, dimensionless unit hydrograph, synthetic hydrograph, and dam breach hydrograph (Indarto, 2015). In this paper, the unit hydrograph (hydrograph unit) is used in flood prediction, which is obtained through the presentation of an isochrone map, which will show the relationship between the time and area of water flowing into the outlet.

The Unit Hydrograph (UH) of a watershed is defined as the direct runoff hydrograph as a result of a constant intensity of excess rainfall's volume that is distributed uniformly over the drainage area for a specific duration of effective rainfall. When dealing with a rainfall of different duration, a new unit hydrograph must be derived for the new duration. The fundamental assumptions for modeling hydrologic systems using unit hydrographs are a) Watersheds respond as linear systems, which implies that the proportionality principle that is scaled accordingly; b) The effective rainfall intensity is uniformly distributed over the entire river basin; c) The rainfall excess is of constant intensity throughout the rainfall duration; and d) The duration of the direct runoff hydrograph (time base) is independent of the effective rainfall intensity and depends only on the effective rainfall duration (Ramírez, 2000). The unit volume is usually considered to be associated with $1 \mathrm{~cm}$ (1 inch) of effective rainfall distributed uniformly over the basin area (Environmental Systems Research Institute, 2018; Ramírez, 2000).

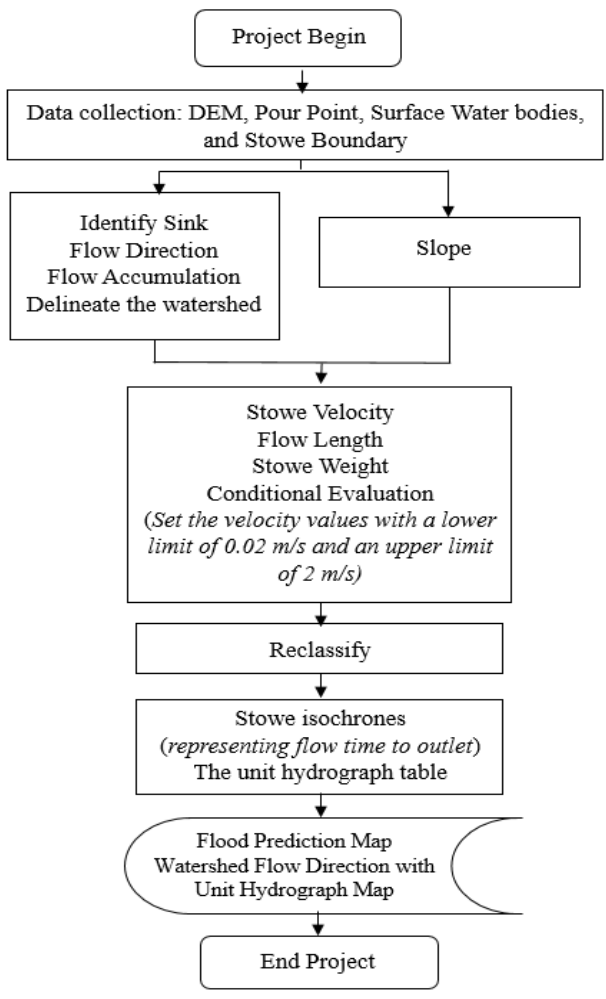

Figure 4. Flowchart of a Research Process 


\section{RESULT AND DISCUSSION}

Isochrone maps are one way of analyzing a spatiotemporal phenomenon such as accessibility that changes through space over time, so in order to determine the number of potential users in a study area, we need to know the location of these people through time (van den Berg et al., 2018). For the same reason, isochrones need to be mapped to determining how long it takes water to reach the outlet, how fast the water flows (velocity), and the extent of the watershed (by calculating the slope and flow accumulation area). To determine the watershed, there are two components that are needed, i.e., accurate flow direction and outlet point (Environmental Systems Research Institute, 2018). The following equation is used to calculate a velocity field:

$$
V=V_{m}\left(s^{b} A^{c}\right) /\left(s^{b} A_{m}^{c}\right)
$$

$V_{m}$ is the average velocity of all cells in the watershed, assumed with average value of $V_{m}=0.1$ (Environmental Systems Research Institute, 2018). The quantity $S^{b} A_{m}^{c}$ is the average slope-area term across the watershed, i.e., the number of cells that flow into that cell, or flow accumulation. Each cell in the velocity field is assigned a velocity based on the local slope generated from the DEM layer, and the upstream contributing area generated from the Stowe fill flow accumulation layer.

Unit hydrograph analysis refers only to direct runoff and base flow, which is composed of contributions from delayed interflow (the portion of the streamflow contributed by infiltrated water that moves laterally in the subsurface until it reaches a channel) and groundwater runoff (the flow component contributed to the channel by groundwater). Groundwater runoff is extremely slow as compared to surface runoff (Ramírez, 2000). In this case UH model structure is assumed to be appropriate to represent catchment behavior.

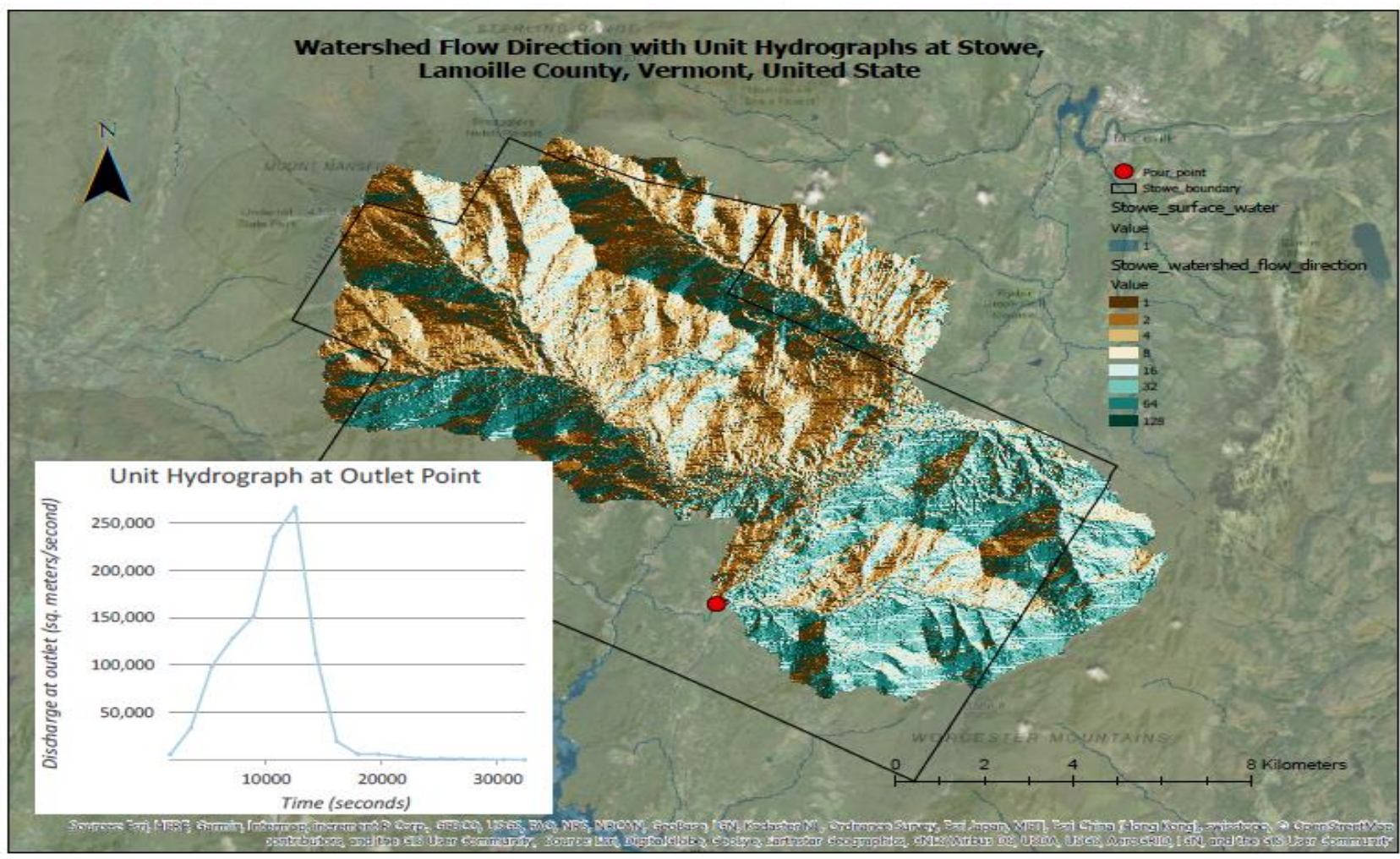

Figure 5. Watershed Flow Direction with Unit Hydrograph with 10 meters DEM's resolution

Total streamflow hydrographs are usually conceptualized as being composed of: a) direct runoff, which is composed of contributions from surface runoff (the main contributor to the peak discharge, includes all overland flow as well as all precipitation falling directly to the stream channels) and quick interflow (slower 
than surface runoff, includes quick interflow that contributes to direct runoff, and delayed interflow, which contributes to base flow) (Ramírez, 2000).

The cell values in a flow direction raster layer can normally be one of only eight integers (see Figure 6) : $1,2,4,8,16,32,64$, and 128, which corresponds to the eight possible flow directions (Environmental Systems Research Institute, 2018). Figure 5 shows Stowe watershed flow direction is to estimate for each cell, the adjacent cell into which water would flow, i.e., 1 and 2 towards the east and southeast. Water that falls in the western mountains takes longer than water that falls on the low-lying stream beds closest to the outlet.

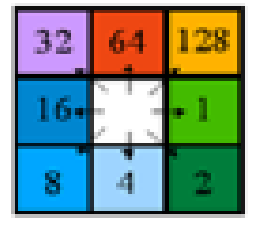

Figure 6. Flow Direction Coding

Flow time is calculated as the length that water must flow divided by the velocity at which it flows (the first equation). There are two variables to determine flow length, i.e., flow direction layer and weight layer (the third equation), which is represent an impedance, example water flowing through forested land takes longer than water flowing over smooth rock because it's impeded by terrain). An equation to calculate flow time (Environmental Systems Research Institute, 2018):

$$
\begin{aligned}
& \text { Flow time }[T]=\text { Flow Length }[\mathrm{L}] / \text { Velocity }[\mathrm{LT}-1] \ldots \ldots . . . \\
& \text { Flow time }[\mathrm{T}]=\text { Flow Length }[\mathrm{L}] \text { * Weight }[\mathrm{L}-1 \mathrm{~T}] \text {.......... }
\end{aligned}
$$

By combining these equations:

$$
\text { Weight }[\mathrm{L}-1 \mathrm{~T}]=1 / \text { Velocity }[\mathrm{LT}-1]
$$
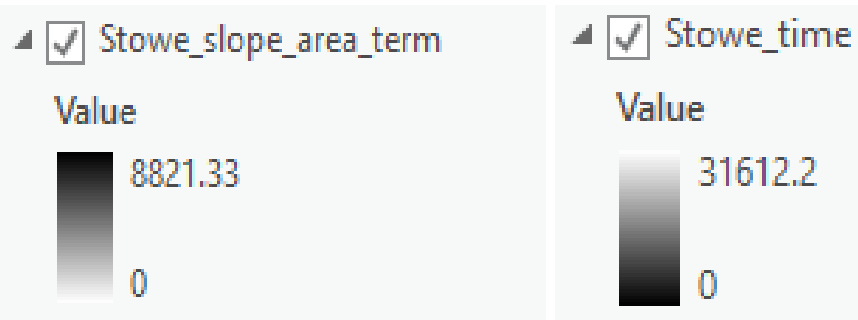

Figure 7. Stowe_slope_areaterm and Stowe_time which has been Processed

The Stowe_time layer shows the time it takes water to flow to the outlet ranges from 0 seconds (rain that falls on the outlet itself) to about 31612 seconds or \pm 8 hours and 46 minutes. The last map as an output of this project is an isochrones map (Figure 9) shows contour lines of locations where the water flow exhibits equal travel time to the outlet of the watershed. This time interval should be appropriate for the Stowe watershed with a time interval of 1800 seconds for every cell per isochrone zone (Environmental Systems Research Institute, 2018). These time intervals as the ordinate of the unit hydrograph.

A DEM with a resolution of 30 meters is also used for additional analysis. The results of DEM processing with a resolution of 30 meters also show relatively the same time and water flow trends. However, it can be seen in Figure 8 that the Hydrograph unit has a better curve because the DEM 10 meter resolution more accurately displays fluctuating differences (discharge of outlets). The Stowe_time layer shows the time it takes water to flow to the outlet ranges from 0 seconds (rain that falls on the outlet itself) to about 48,600 seconds or \pm 13 hours 30 minutes. The three hours different have a big impact on rescue time when the hazard happens. 
Based on the amount of water has accumulated, the area around Stowe is no exception, indicating that water will flow at its fastest when funneling toward the outlet point downstream of the town.

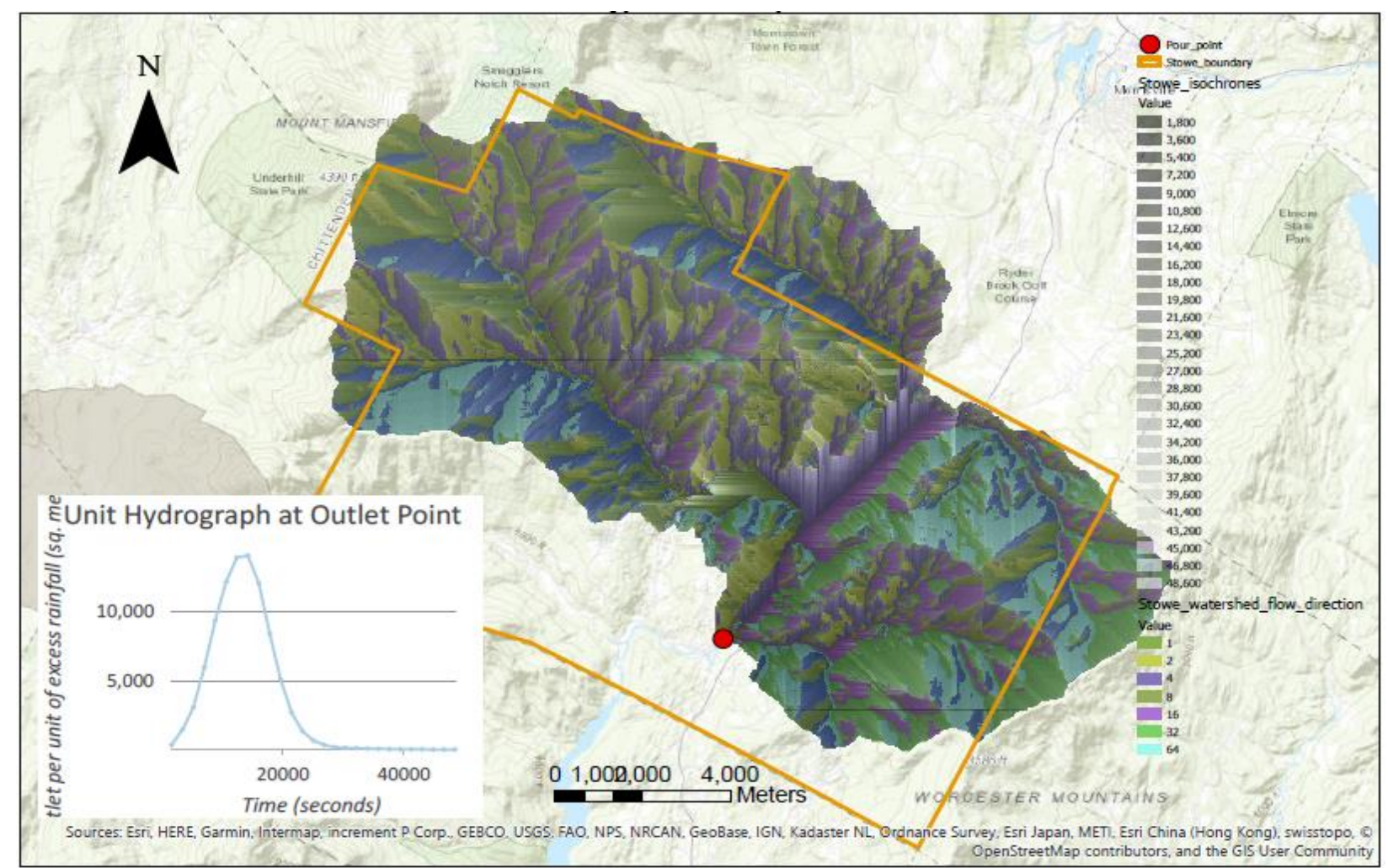

Figure 8. Watershed Flow Direction with Unit Hydrograph with 30 meters DEM's resolution

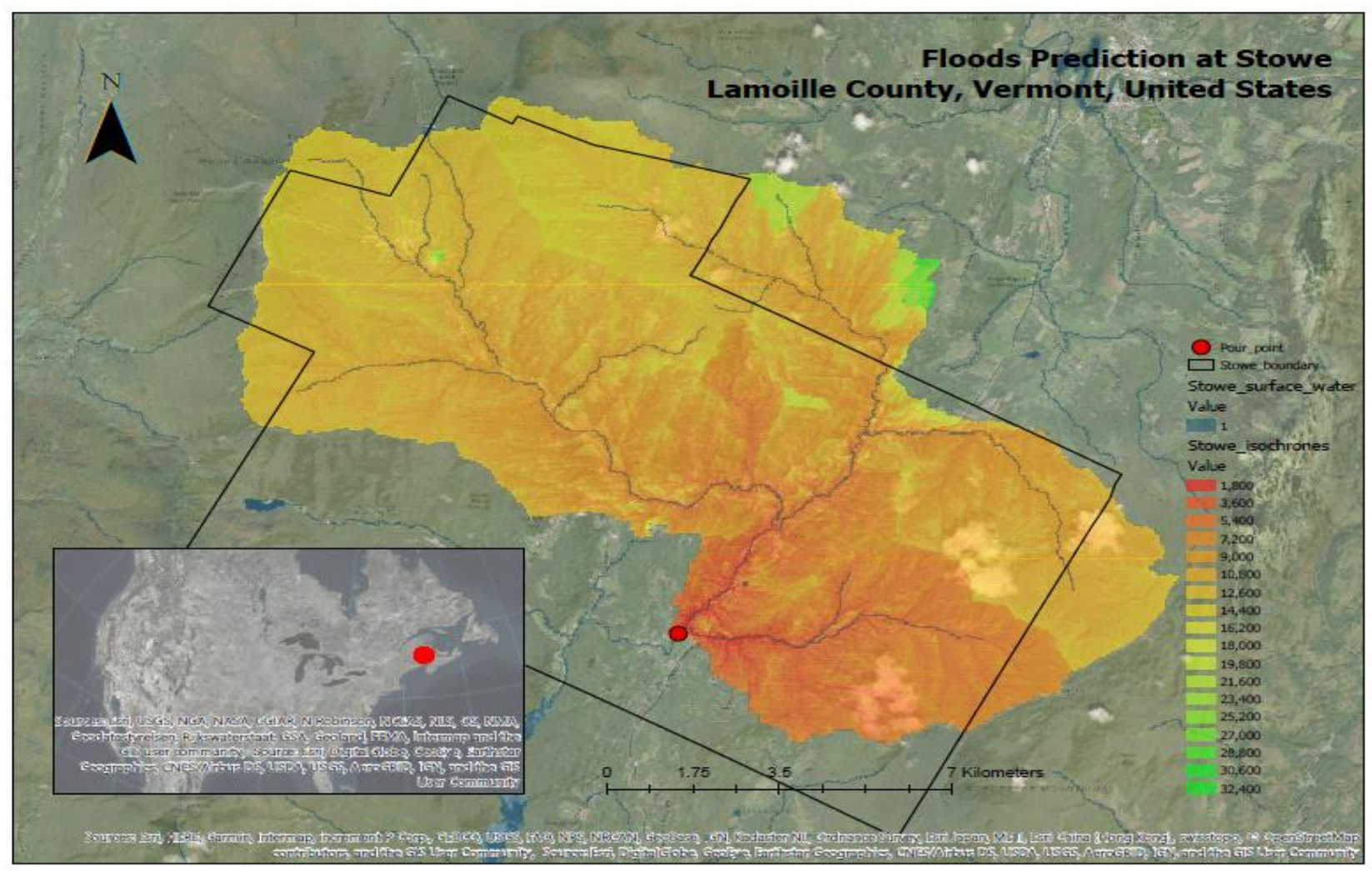

Figure 9. Flood prediction of The West Branch of Little River, Stowe with 10 meters DEM's resolution 


\section{CONCLUSION}

This paper shows contour lines of locations where the water flow exhibits equal travel time to the outlet of the watershed, which is an adjacent cell into integer 1 and 2 towards east and southeast that falls on the low-lying stream beds closest to the outlet. The water that falls in the northeast of the study area takes the most prolonged (in time) than the other direction because the water flowing through forested land takes longer than water flowing over a smooth rock because the plants impede it. From data processing,

The Stowe_time layer shows the time it takes water to flow to the outlet ranges from 0 seconds (rain that falls on the outlet itself) to about 31612 seconds or \pm 8 hours and 46 minutes, using DEM with 10 meters resolution, and about 48,600 seconds or \pm 13 hours 30 minutes, using DEM with 30 meters resolution. Both of them show the same unit hydrograph and the trend for water flow relatively. But, the three hours different have a big impact on rescue time when the hazard happens. Based on the amount of water has accumulated, the area around Stowe is no exception, indicating that water will flow at its fastest when funneling toward the outlet point downstream of the town.

\section{ACKNOWLEDGMENTS}

The writers would like to thank ESRI, USGS, Vermont Center for Geographic Information (VCGI), and The Lamoille County Planning Commission, who provided data, related document, tutorial, insight, and expert input that greatly assisted the research, although they may not agree with all of the interpretations/conclusions of this paper. The writers would like to thank Dr. Peter J. Voice as an advisor for this research. The writers also thank the Ministry of Research, Technology, and Higher Education of Indonesia through the RISET-PRO scholarship 2017 (Nr. 264/RISET-Pro/FGS/VIII/2017).

\section{REFERENCES}

Allen, D. W. (2011). Getting to know ArcGIS modelBuilder. Esri Press.

Armstrong, K. (2009). Modelbuilder: An introduction. Esri Southeast Regional User Group Conference. Jacksonville, Florida: ESRI.

Csáfordi, P., Podör, A., Bug, J., \& Gribovsyki, Z. (2012). Soil erosion analysis in a small forested catchment supported by ArcGIS Model Builder. Acta Silvatica et Lignaria Hungarica, 8(1), 39-55. [Crossref]

Environmental Systems Research Institute. (2018). Predict Floods with Unit Hydrographs.

Guéro, P. (2006). Rainfall Analysis and Flood Hydrograph Determination in the Munster Blackwater Catchment. University College Cork.

Indarto. (2015). Hidrologi: Metode Analisis dan Tool untuk Interpretasi Hidrograf Aliran Sungai. Jakarta: Bumi Aksara.

Khan, S., Yufeng, L., \& Ahmad, A. (2009). Analysing complex behaviour of hydrological systems through a system dynamics approach. Environmental Modelling \& Software, 24(12), 1363-1372. [Crossref]

Kraemer, C., \& Hale, R. (2014). ArcGIS: Model Builder Workshop.

Kumalawati, R., Sartohadi, J., Pradiptyo, R., Samsurijal, S., \& Prasaja, A. S. (2013). Klasifikasi Kerusakan Permukiman Akibat Banjir Lahar Menggunakan Model Builder GIS. Seminar Nasional Pendayagunaan Informasi Geospatial Untuk Optimalisasi Otonomi Daerah 2013, 81-84. Surakarta: Universitas Muhammadiyah Surakarta.

Kusumastuti, D. I., \& Jokowinarno, D. (2012). Time Step Issue in Unit Hydrograph for Improving Runoff Prediction in Small Catchments. Journal of Water Resource and Protection, 4(8), 686-693. [Crossref]

Maxwell, A. R., \& Papanicolaou, A. N. (2001). Step-Pool Morphology in High-Gradient Streams. International Journal of Sediment Research, 16(3), 380-390.

Omran, A., Schroder, D., El Rayes, A., \& Geriesh, M. (2011). Flood hazard assessment in Wadi Dahab, Egypt based on basin morphometry using GIS techniques. In A. Car, G. Griesebner, \& J. Strobl (Eds.), Geospatial Crossroads @GI_Forum '11. Herbert Wichmann Verlag, VDE VERLAG GMBH, Berlin/Offenbach. 
Ramírez, J. A. (2000). Prediction and Modeling of Flood Hydrology and Hydraulics. In E. Wohl (Ed.), Chapter 11 of Inland flood hazards: Human, riparian and aquatic communities. Cambridge university press. [Crossref]

Sulebakk, V. (2017). Identification and analysis of step-pool morphometry: A study of geometric relations and spatial distributions in step-pools, following automated identification of bed morphology from a longitudinal profile. Norwegian University of Science and Technology.

The Lamoille County Planning Commission. (2006). West branch of the little river corridor management plan Stowe, Vermont.

The U.S. Department of Agriculture. (2007). Chapter 16 Hydrographs. In Part 630 Hydrology National Engineering Handbook (p. 50). The U.S. Department of Agriculture (USDA).

van den Berg, J., Köbben, B., van der Drift, S., \& Wismans, L. (2018). Towards a Dynamic Isochrone Map: Adding Spatiotemporal Traffic and Population Data. In P. Kiefer, H. Huang, N. de Weghe, \& M. Raubal (Eds.), Progress in Location Based Services 2018 (pp. 195-209). [Crossref]

Weaver, J. C. (2003). Methods for estimating peak discharges and unit hydrographs for streams in the city of Charlotte and Mecklenburg County, North Carolina. Raleigh, North Carolina. [Crossref]

Zandbergen, P. A. (2015). Python Scripting for ArcGIS. Esri Press.

Zhu, Z. (2010). An earthquake-induced landslides risk assessment model using the modelBuilder of ArcGIS. 2010 18th International Conference on Geoinformatics, 1-4. [Crossref] 